\title{
ANTICANCER, CYTOTOXIC EFFECT OF TAMARIX APHYLLA, AND ANTIBACTERIAL SCREENING EFFICIENCY AGAINST MULTIDRUG-RESISTANT HUMAN PATHOGENS
}

\author{
SANAD M AL SOBEAI* \\ Department of Sajir College of Arts and Science, Shaqra University, Shaqra, Saudi Arabia. Email: Salsobaei@su.edu.sa
}

Received: 14 May 2018, Revised and Accepted: 09 July 2018

\begin{abstract}
Objectives: The present study aimed to investigate the anticancer, cytotoxic effect of Tamarix aphylla, and antibacterial effectiveness against 10 pathogenic bacteria that cause common and sometimes serious infections in human and animals.
\end{abstract}

Methods: T. aphylla fresh and disease-free leaves were collected from the different geographical regions of Saudi Arabia. The anticancer, cytotoxic effect of T. aphylla leaves, and antibacterial screening efficiency against multidrug-resistant human pathogens were investigated in vitro using Vero cells as a normal cells and MCF-7 (breast adenocarcinoma cells).

Results: T. aphylla leaf extracts exhibited a low cytotoxic effect on Vero cell line at high concentration, with an $50 \%$ cytotoxicity concentration value of $>1000 \mu \mathrm{g} / \mathrm{ml}$. The methanolic extract inhibited MCF-7 cancer cells in a concentration-dependent manner. The methanol and ethanol extracts showed antibacterial activity with variable inhibition effects and differences in their activities against tested pathogenic bacteria ranging from very high inhibition $(20.7 \pm 1.3 \mathrm{~mm})$ to low $(4 \pm 0.6 \mathrm{~mm})$. The minimum inhibitory concentration of methanol and ethanol results showed no significant differences.

Conclusions: The findings of this study conclude that the T. aphylla leaf extract had lower toxicity on normal cell line (low toxic plant) and significantly inhibited the growth of cancer cells. T. aphylla has potential antibacterial biomolecules against multidrug-resistant human pathogens.

Keywords: Tamarix aphylla, Leaves, Cytotoxic activity, African green monkey kidney cells (Vero) and breast adenocarcinoma cells (MCF-7), Anticancer effect, antibacterial.

(C) 2018 The Authors. Published by Innovare Academic Sciences Pvt Ltd. This is an open access article under the CC BY license (http://creativecommons. org/licenses/by/4. 0/) DOI: http://dx.doi.org/10.22159/ajpcr.2018.v11i11.27309

\section{INTRODUCTION}

The use of medicinal plants in the community increased in the recent years for curing some health-related diseases [1,2] and has been generally used in many different parts of the world [3].

The medicinal plants possess antimicrobial effects which have received more attention in the past few years [4]. In some communities, consuming herbal drugs and traditional medicine is somewhat more popular because of cultural acceptability and belief that being natural, and also, it is considered as the cheapest and safer sources for discovering new effective antimicrobials [5]. Medicinal plant has been identified by the World Health Organization (WHO) as any plant which contains active compounds that can be used for therapeutic tools or which are pioneers for the synthesis of effective safe drugs [6]. Several drugs and pharmaceuticals constitute approximately $40 \%$ plant source [1]. Infectious diseases are a common major global challenge for medical, scientific communities, health organizations, and pharmaceutical companies around the world. It has been estimated that 50,000 deaths every day especially with the current increasing trends of multidrug resistance among emerging and re-emerging bacterial pathogens to the many available antibiotics $[5,6]$.

Cancer is a global major health problem, it is the second leading cause of death Worldwide [7,8], and about 14 million new cases and 8.2 million cancer-related deaths were reported in 2012 [7-9]. The global incidence of cancer is more 11 million with up to 7.6 million deaths, in which $72 \%$ of these deaths were in low-income and middleincome countries $[9,10]$, and is expected to increase to an incidence of 15.5 million with 11.5 million deaths by 2030 [7-9].

The WHO reported that $80 \%$ of the population worldwide practices herbal medicine for cure primary health cases [11]. Currently, $50 \%$ of all drugs in the market and $74 \%$ of the most important drugs are derived from phytochemicals $[9,11]$. Currently, more than $60 \%$ of commercially available anticancer drugs are derived from natural sources, including plants, marine organisms, and microorganisms [9,12]. To date, more than 3000 different plant species have been used in the treatment of different types of cancer $[9,11]$. Extensive research on medicinal plants has identified several botanical natural compounds that have chemopreventive potential [12]. Plant bioactive molecules and phytochemicals could prevent more $20 \%$ of cases of cancer and may potentially prevent approximately 200,000 cancer-related deaths annually. Due to their safety, low toxicity, and antioxidant properties, several plants are being investigated for the prevention of cancer $[9,10]$. Tamaricaceae is comparatively a small family containing 4 genera and about 120 species of flowering plants [15]. Members of the family are mostly temperate and subtropical, growing in marine or sandy habitats. Geographically, this plant distributed in the Mediterranean, North Africa, and south-western Africa through the Arabian Peninsula to Central and South Asia [15].

Tamarix is distributed in Saudi Arabia with eight species, namely Tamarix mascatensis Bunge., Tamarix ramosissima Ledeb., Tamarix nilotica (Ehrenb.) Bunge., Tamarix aphylla L., Tamarix tetragyna Ehrenb., Tamarix aucheriana Decne., Tamarix pyconocarpa DC, and Tamarix passerinoides Del $[13,14]$. Several studies revealed that some Tamarix species have been used as a diaphoretic, diuretic, and hepatotonic and to treat liver disorders, to relieve headache, anti-inflammatory, ease prolonged, or difficult labor, and to treat sores and wounds $[13,15,16]$. Different parts of Tamarix are used; the leaves and young branches for edema of the spleen are mixed with ginger for uterus infections, while bark part is used as lotion against lice, eyes sore, and hemorrhoid [15]. Tamarix species contain different classes of natural products $[13,16]$. Various secondary metabolite compounds have been isolated as a 
carbohydrate, phenols, flavonoids, terpenoids, steroids, tannins, and cardiac glycosides, and due to the existence of these compounds, the Tamarix has been shown to have antibacterial, antifungal, antiseptic, and anti-parasitic actions [2,13,15]. It is, therefore, very necessary that the search for newer medicinal based antibiotic sources to be a continued process.

The present study aims to investigate the anticancer, cytotoxic effect of T. aphylla, and antibacterial screening efficiency against 10 pathogenic bacteria that cause common and sometimes serious infections in human and animals.

\section{METHODS}

\section{Collection of T. aphylla samples}

T. aphylla fresh and disease-free leaves were collected from the different geographical regions of Saudi Arabia. The taxonomic and morphological identification of the plant material was confirmed by Herbarium Center at the Botany and Microbiology Department, King Saud University. The plant was morphologically identified by Herbarium Center at the Botany and Microbiology Department, King Saud University. The plant samples were sealed in sterilized polythene bags, were brought to the laboratory, and were washed thoroughly 2-3 times with running tap water and once with sterile water, left at room temperature for 3-5 days in the dark, then oven-dried for $1 \mathrm{~h}$ at $160^{\circ} \mathrm{C}$, and placed at $37^{\circ} \mathrm{C}$ till complete drying, and then, whole plant was ground using sterile coffee grinder into a fine powder.

\section{Extraction with ethanol and methanol}

The prepared powder was soaked in each of ethanol and methanol solvents $(10 \mathrm{~g}$ in $100 \mathrm{ml})$ and extracted for $24 \mathrm{~h}$ at room temperature with shaking at $150 \mathrm{rpm}$. After filtration through a Whatman no. 4 filter paper, solvents were evaporated under reduced pressure using R-215 Rotary Evaporator (Sigma-Aldrich) until dryness. The solventfree brownish crude extract thus was obtained and was re-suspended in dimethyl sulfoxide (DMSO) or phosphate-buffered saline (PBS) to a final stock concentration of $50 \mathrm{mg} / \mathrm{ml}$ or $100 \mathrm{mg} / \mathrm{ml}$. All extracts were stored at $4^{\circ} \mathrm{C}$ in airtight dark bottles till use $[17,18]$.

\section{Test pathogenic bacterial species}

Bacterial species used in this study (Table 1) were clinical isolates obtained from the Botany and Microbiology Department, Faculty of Science, King Saud University. All of the bacterial species were grown and maintained on Mueller-Hinton agar or trypticase soy agar media at $37^{\circ} \mathrm{C} \mathrm{pH}$ $(7.3 \pm 0.2)$. All bacterial species were identified and characterized by culturing in the specific appropriate media followed by the rapid testing (Gram's stain, catalase, oxidase, coagulase, and bile solubility) and the biochemical testing (indole, methyl red, VogesProskauer, citrate, triple sugar iron, oxidation/fermentation, urease, and nitrate reduction).

\section{Bacterial species inoculums}

The tested bacterial species were first inoculated into tubes which contain Mueller-Hinton Broth separately and incubated at $37^{\circ} \mathrm{C}$ for $18 \mathrm{~h}$. Each of the cultures was then adjusted to $0.5 \mathrm{McF}$ arland Turbidity

Table 1: Bacterial species, media, and cultivation conditions

\begin{tabular}{lll}
\hline No. & Bacterial species & Media and cultivation conditions \\
\hline 1 & Klebsiella pneumoniae & $\mathrm{TSA}+\mathrm{YE}$ or $\mathrm{MHA}, 37^{\circ} \mathrm{C}$ \\
2 & Proteus mirabilis & $\mathrm{TSA}+\mathrm{YE}$ or $\mathrm{MHA}, 37^{\circ} \mathrm{C}$ \\
3 & Enterococcus faecalis & $\mathrm{TSA}+\mathrm{YE}$ or $\mathrm{MHA}, 37^{\circ} \mathrm{C}$ \\
4 & Staphylococcus aureus & $\mathrm{TSA}+\mathrm{YE}$ or $\mathrm{MHA}, 37^{\circ} \mathrm{C}$ \\
5 & Salmonella typhi & $\mathrm{TSA}+\mathrm{YE}$ or $\mathrm{MHA}, 37^{\circ} \mathrm{C}$ \\
6 & Streptococcus pyogenes & $\mathrm{TSA}+\mathrm{YE}$ or $\mathrm{MHA}, 37^{\circ} \mathrm{C}$ \\
7 & Shigella sonnei & $\mathrm{TSA}+\mathrm{YE}$ or $\mathrm{MHA}, 37^{\circ} \mathrm{C}$ \\
8 & Pseudomonas aeruginosa & $\mathrm{TSA}+\mathrm{YE}$ or MHA, $37^{\circ} \mathrm{C}$ \\
9 & Listeria monocytogenes & $\mathrm{TSA}+\mathrm{YE}$ or MHA, $37^{\circ} \mathrm{C}$ \\
10 & Bacillus subtilis & $\mathrm{TSA}+\mathrm{YE}$ or $\mathrm{MHA}, 37^{\circ} \mathrm{C}$ \\
\hline
\end{tabular}

TSA: Trypticase soy agar, YE: Yeast extract, MHA: Mueller-Hinton agar
Standard at $1-2 \times 10^{6} \mathrm{CFU} / \mathrm{mL}$ and inoculated $(0.1 \mathrm{ml}$ each) onto Mueller-Hinton agar plates (diameter: $15 \mathrm{~cm}$ ).

\section{Maintenance of cell lines}

African green monkey kidney cells (Vero) and breast adenocarcinoma cells (MCF-7) were cultured in Dulbecco's Modified Eagle's Medium (DMEM) supplemented with 10\% fetal bovine serum (FBS; Gibco, Grand Island, NY), $2 \mathrm{mM} \mathrm{L-glutamine,} \mathrm{penicillin}(100 \mathrm{U} / \mathrm{ml})$, streptomycin $(100 \mu \mathrm{g} / \mathrm{ml})$, and amphotericin B $(0.25 \mu \mathrm{g} / \mathrm{ml})$ (Sigma, St. Louis, MO). Cells treated with medicinal plant extracts were kept in maintenance medium containing 1\% FBS, L-glutamine, and antibiotics. Cells were incubated at $37^{\circ} \mathrm{C}$ with $5 \% \mathrm{CO}_{2}$ for 3 days.

\section{Evaluation of Vero cell morphology}

Monolayer cultures of monkey kidney cells (Vero) (80-90\% confluence) were prepared in 96-well plates. After removal of culture medium, cells were washed twice with PBS. Two-fold serial dilutions of the methanol, ethanol, and water extracts were prepared in maintenance medium starting from the concentration of 2500 to $4 \mu \mathrm{g} / \mathrm{ml}$ and added to cells in triplicates. Wells that received ethanol $70 \%$ or DMSO were served as positive controls and those that received maintenance media only were served as negative controls. All cultures were kept at $37^{\circ} \mathrm{C}$ in $\mathrm{CO}_{2}$ incubator for $72 \mathrm{~h}$ with daily observation for morphological changes under phase-contrast inverted microscope equipped with a digital camera (Olympus IX51, Tokyo, Japan) at $\times 20$ and $\times 40$. Cellular alterations were recognized in the form of cell rounding, granulation, vacuolation, degeneration, and lysis, as well as detachment of the monolayer. The minimal toxic concentration (MTC) was identified as the least concentration that induces toxic effect(s) on culture cells as detected microscopically 3-4 days post incubation as described by Abdul et al. [21]

\section{Antiproliferative and cytotoxic effect assay}

The cytotoxic effect of the extracts of T. aphylla leaf against Vero cells as a normal cells and MCF-7 (breast adenocarcinoma cells) was determined by a rapid colorimetric assay, using cell titer-blue (CTB) reagent (Promega, Madison, WI). The color is quantified using multi-well ELx880 microplate reader (ELISA reader) (BioTek, Winooski, VT) with wavelength $570 \mathrm{~nm}$ (ELISA reader). Briefly, $180 \mu \mathrm{l}$ of cell suspension $(2 \times 104 \mathrm{cell} / \mathrm{ml})$ was seeded in 96 -well microplates except for the first row which contained only $180 \mu \mathrm{l}$ of DMEM which was considered as the blank. After $24 \mathrm{~h}$ of incubation in the previously mentioned conditions, the cells were treated with a $20 \mu \mathrm{l}$ of two-fold dilution series of plant extracts and incubated at $37^{\circ} \mathrm{C}$ for $72 \mathrm{~h}$ in a $\mathrm{CO}_{2}$ incubator. After completion of the treatment period, the $20 \mu \mathrm{l}$ of CTB reagent (Promega, Madison, WI) was added to each well. For the positive control, $20 \mu \mathrm{l}$ of DMSO was added instead of extracts. After $4 \mathrm{~h}$ of incubation at $37^{\circ} \mathrm{C}$, the optical density was measured in all plate wells using ELx880 microplate reader (BioTek, Winooski, VT) with wavelength of $570 \mathrm{~nm}$ [21]. The cell viability was measured in each well using the following formula [21]:

Cell viability $=\frac{\mathrm{OD}(\text { assay well })-\mathrm{OD}(\text { positvecontroll })}{\mathrm{OD}(\text { cell control })-\mathrm{OD}(\text { positivecontrol })} \times 100$

The $50 \%$ cytotoxicity concentration $\left(\mathrm{CC}_{50}\right)$ was calculated as the concentration of the plant extract that induced reduction in cell viability to $50 \%$.

\section{In vitro antibacterial bioassay}

Antibacterial activity of the ethanol, methanol, and aqueous extracts was screened by agar well diffusion method as described by Gawade and Farooqui [20] and Abdul et al. [21]. Briefly, the bacterial suspension was swabbed uniformly to the Petri dishes containing 20-30 MuellerHinton Agar (MHA), and the inoculum was allowed to dry for 5-10 min. Nine wells of 6-8 $\mathrm{mm}$ in diameter were made in the surface of inoculated MHA using sterile cork borer for different concentrations of the extract and controls. The $50 \mu \mathrm{L}$ from each extract $(1,5,10,50,100,200,250$, and $500 \mathrm{mg} / \mathrm{mL}$ ) was added into each well on the MHA plate and allowed to stand on the bench for $1 \mathrm{~h}$ for proper diffusion and thereafter incubated 
at $37^{\circ} \mathrm{C}$ for $24 \mathrm{~h}$. After $24 \mathrm{~h}$, antibacterial activity was determined by measurement of diameter zones of inhibition ( $\mathrm{mm}$ ) (against the tested bacterial species) around each of the extracts. Reference antibiotic disc was placed on the agar surface as positive control. Sterilized distilled water was served as negative controls in a separate well. These studies were performed in triplicate.

Quantitative antibacterial activity assay by minimum inhibitory concentration (MIC) and minimal bacterial concentration (MBC)

The MIC of the aqueous, ethanol, and methanol extracts was determined for the tested bacterial species in triplicates at varying concentrations by tube dilution method. A tube containing $1 \mathrm{ml}$ of Mueller-Hinton broth was inoculated with a loopful of the tested bacteria previously diluted to 0.5 McFarland turbidity standard. A tube containing Mueller-Hinton broth only was seeded with the tested bacteria to serve as a control. All the tubes were then incubated at $37^{\circ} \mathrm{C}$ for $24 \mathrm{~h}$ and then examined for growth by observing turbidity. The MBC of the plant extract on the tested bacterial species was carried out according to Ajaiyeoba et al. [24]. Briefly, $1 \mathrm{ml}$ from the MIC tubes showing no growth was subcultured on to MHA plate and incubated at $37^{\circ} \mathrm{C}$ for $24 \mathrm{~h}$. The MBC was defined as the lowest concentration of bacteria that showed no bacterial colony. All samples were examined in triplicate.

\section{Statistical analysis}

Microsoft Excel (2007) data sheets and GraphPad Prism version 6 were used to analyze the data. $\mathrm{CC}_{50}$ values, which is the concentration that kills $50 \%$ of the test cells. All data were presented as means \pm standard deviation.

\section{RESULTS}

\section{Antibacterial activity}

The result of the antibacterial activity of the extracts obtained from T. aphylla leaves against tested pathogenic bacteria that cause common and sometimes serious infections in human and animals is shown in Fig. 1. The diameter of all inhibition zones was measured and compared. The methanol and ethanol extracts showed antibacterial activity with variable inhibition effects and differences in their activities against tested pathogenic bacteria ranging from very high inhibition $(20.7 \pm 1.3 \mathrm{~mm})$ to low $(4 \pm 0.6 \mathrm{~mm})$. Antibacterial activities were expressed as mean inhibition diameter zones of the three replicates in millimeters $(\mathrm{mm})$. Zone of inhibition does not include the diameter of the well. Both methanolic and ethanolic extracts of T. aphylla leaves showed relatively similar antibacterial activity and inhibition effects against Gram-positive and negative bacteria. Highest antibacterial activity was observed with ethanol and methanol extract against
Klebsiella pneumoniae $(17 \pm 0.7 \mathrm{~mm}$ and $16 \pm 0.6 \mathrm{~mm})$, Streptococcus pyogenes $(14.7 \pm 0.6 \mathrm{~mm}$ and $14 \pm 0.6)$, Shigella sonnei $(13 \pm 0.7 \mathrm{~mm}$ and 13 \pm 0.7$)$, and Enterococcus faecalis $(12 \pm 0.5 \mathrm{~mm}$ and $11 \pm 0.6 \mathrm{~mm})$, respectively, while the modest antibacterial activity was showed against Salmonella typhi $(10 \pm 0.7 \mathrm{~mm}$ and $9 \pm 0.7 \mathrm{~mm})$, Staphylococcus aureus $(10 \pm 0.7 \mathrm{~mm}$ and $10 \pm 0.7 \mathrm{~mm})$, Pseudomonas aeruginosa $(9 \pm 0.7 \mathrm{~mm}$ and $5 \pm 0.7 \mathrm{~mm})$, Bacillus subtilis $(8.6 \pm 0.6 \mathrm{~mm}$ and $8.6 \pm 0.6 \mathrm{~mm})$, and Proteus mirabilis $(7 \pm 0.5 \mathrm{~mm}$ and $7 \pm 0.5 \mathrm{~mm})$, respectively, whereas the lowest activity was observed against Listeria monocytogenes with inhibition zone about $3 \pm 0.6$ and $1.5 \pm 0.6 \mathrm{~mm}$, respectively (Fig. 1 ). The methanol and ethanol extract results showed overall similar antibacterial activity against tested organisms. Noticeably, only a small inhibition was observed with methanol extract against L. monocytogenes (Fig. 1).

\section{The MIC}

The MIC was determined for T. aphylla extracts which were found active in the antibacterial activity evaluation (Fig. 1). The MIC ranged from 1 to $20 \mathrm{mg} / \mathrm{ml}$ (Fig. 2). The MIC of methanol and ethanol results showed no significant differences. The MIC of methanol extract was 20, 20, 15, $10,10,10,5,5,5$, and $1 \mathrm{mg} / \mathrm{ml}$ for K. pneumonia, S. pyogenes, $S$. sonnei, E. faecalis, S. typhi, S. aureus, P. aeruginosa, B. subtilis, P. mirabilis, and L. monocytogenes, respectively, while the MIC values of ethanol extract were $22,20,15,15,15,10,10,5,5$, and $1.5 \mathrm{mg} / \mathrm{ml}$ for $K$. pneumonia, S. pyogenes, S. sonnei, E. faecalis, S. typhi, S. aureus, P. aeruginosa, B. subtilis, P. mirabilis, and L. monocytogenes, respectively (Fig. 2).

\section{Cytotoxicity of $T$. aphylla extracts}

The cytotoxic activity was evaluated in vitro according to it is effect on cell morphology (microscopic examination) and the metabolic reduction of CTB reagent (colorimetric assay) Vero cells. The multiple concentrations of T. aphylla leaf extracts were used and $\mathrm{CC}_{50}$ doses were calculated. T. aphylla leaf extracts exhibited low cytotoxic effect on Vero cell line at high concentration, with an $\mathrm{CC}_{50}$ value of $>1000 \mu \mathrm{g} / \mathrm{ml}$. The MTC colorimetric assay was determined for which the value was $2000 \mu \mathrm{g} / \mathrm{ml}$. It was also shown that all treatments displayed a percentage of growth inhibition activity in a dose-dependent manner. The results of the cytotoxicity evaluation against Vero cell of T. aphylla leaf extracts revealed that this plant might be non-toxic plant.

\section{Phase-contrast microscopy for morphological analysis}

Morphological change investigation using phase-contrast microscopy revealed that $T$. aphylla leaf extracts decreased the number of cells and induced cell shrinkage and cell detachment of the monolayer surface of cells treated with high concentration $2500 \mu \mathrm{g} / \mathrm{ml}$ (Table 2). Morphological alterations and cytopathic effect forming of Vero cells

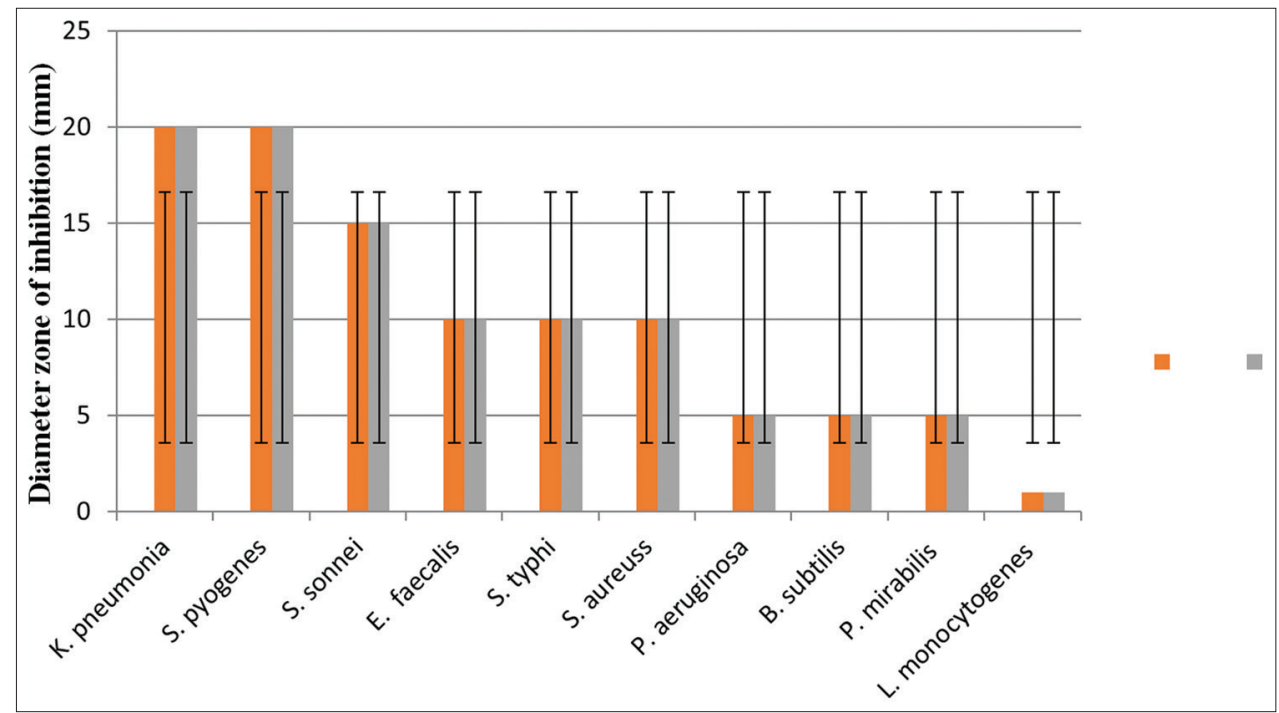

Fig. 1: Antibacterial activities profile (inhibitory zone in diameter) of ethanol and methanol extracts at $50 \mathrm{mg} / \mathrm{ml}$ against tested bacterial species. Values are mean of three replicates 


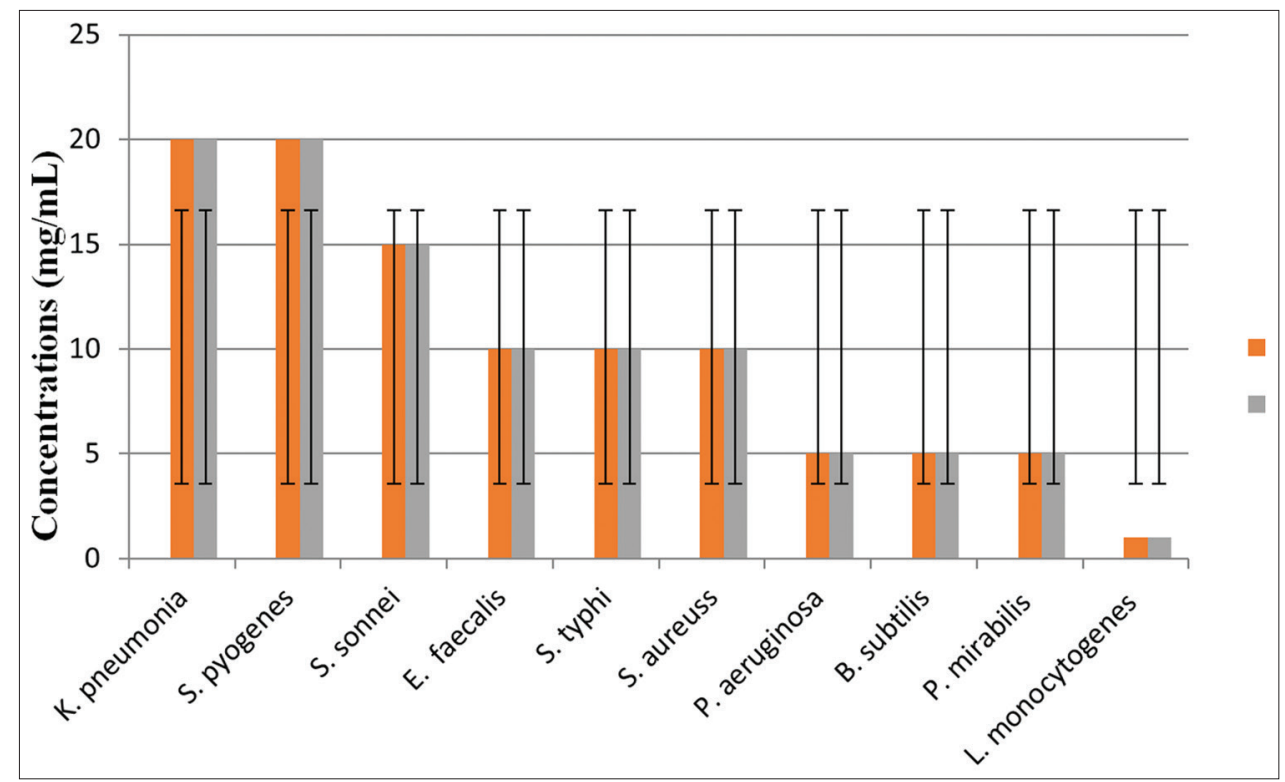

Fig. 2: Minimum inhibitory concentration values of methanol and ethanol leaf extracts with standard deviation against tested bacteria

Table 2: In vitro microscopic cell-based cytotoxicity assay (Vero cell line)

\begin{tabular}{|c|c|c|c|c|c|c|c|c|c|c|c|}
\hline \multirow[t]{2}{*}{ Extracts } & \multicolumn{11}{|c|}{ Concentrations $(\mu \mathrm{g} / \mathrm{ml})$} \\
\hline & 2000 & 1000 & 500 & 250 & 125 & 64 & 32 & 16 & 8 & 4 & $\mathbf{0}$ \\
\hline Methanol and ethanol & + & \pm & - & - & - & - & - & - & - & - & - \\
\hline
\end{tabular}

+: Positive (morphological alterations, CPE forming), -: Negative (No morphological alterations no CPE), CPE: Cytopathic effect

treated with T. aphylla leaves extracts ( 4 and $2500 \mu \mathrm{g} / \mathrm{ml}$ ), versus untreated cells. The maximum concentration of methanol, ethanol, and water extracts from $T$. aphylla used in cell viability assay was $2500 \mu \mathrm{g} / \mathrm{ml}$, and the result is presented in Table 2. This result incited us to look for another in vitro test to study the effect of extracts on MCF-7 cancer cell viability.

Inhibitory effects of T. aphylla leaf extracts on breast adenocarcinoma cells

The antiproliferative effect of both ethanol and methanol extracts of T. aphylla leaves were investigated against MCF-7 (Fig. 3). All methanolic and ethanolic extract inhibited MCF-7 cancer cells in a dose-dependent manner. At the lower concentrations $(4-16 \mu \mathrm{g} / \mathrm{ml})$, statistically no significant decrease of cell growth was observed. However, at the concentrations of $500-1000 \mu \mathrm{g} / \mathrm{ml}$, the plant extract significantly inhibited the growth of MCF-7 cells as compared to the control ones (Fig. 3). For instance, $500 \mu \mathrm{g} / \mathrm{ml}$ ethanol and methanol extracts inhibited the cell growth by 55\% (Fig. 3).

\section{DISCUSSION}

The major challenge facing the medical and public community is the shortage of antimicrobial compounds. This has arisen due to the overprescribing of unnecessary antibiotics and other antimicrobials; as a consequence of bacterial resistance, arising to antimicrobial compound [25], [26]. Medicinal plants remain a major of potentially useful structures for the development of new chemotherapeutic agents [17]. The firststep toward this purpose is the in vitro cytotoxicity, anticancer, and antibacterial activity assessment. Many studies have been screened antiviral, antibacterial, antifungal, anthelmintic, and anti-inflammatory properties of plants and whether they contain compounds with therapeutic activity or not [25-29]. Some of these observations have helped in identifying the active principle responsible for such activities, and in the developing drugs for the therapeutic use in human beings, antimicrobials of plant origin are effective in the treatment of several infections [27].
Recent scientific research has shown that many plants used in traditional medicine are potentially toxic, allergic, mutagenic, and/or carcinogenic $[30,19]$. Therefore, in vitro cytotoxic evaluation studies are important to obtain the effective safe new gents that have certain desirable properties such as little or no toxic effects on normal cells, high efficacy on multiple sites, capability of oral consumption, known mechanism of action, low cost, and acceptance in the community [32]. Cytotoxicity testing of medicinal plants is not only important to evaluate and validate the safety of medicinal plants for traditional use but also provides guidance in the search for new active compounds.

In the present study, the cytotoxic effect of the methanol and ethanol extracts of the Tamarix were investigated in vitro on Vero cells using CTB reagent. The cytotoxicity was evaluated on Vero cells in a dosedependent manner at the end of $72 \mathrm{~h}$ incubation. The cytotoxicity indices low degrees of cellular degeneration at high concentration. In this regard, it is worthy to mention that the mean $\mathrm{CC}_{50}$ value of methanol and ethanol extracts in this study was lower than $1000 \mu \mathrm{g} / \mathrm{ml}$ (Table 2) (Fig. 3). In vitro cytotoxicity results indicated that the T. aphylla could not be belonging to the toxic plant. Therefore, the results obtained in this study supported that the T. aphylla might be considered as pro-missing candidates for further evaluation against different kinds of other cell types both in vitro and in vivo.

The antiproliferative effect of T. aphylla leaves was investigated against MCF-7 cells. The Vero cells were used for comparisons between normal and cancer cells in this study, and the result showed that the extract does not show any apparent cytotoxicity against the normal cells. Results indicated that the T. aphylla leaf extracts inhibited the proliferation of MCF-7 cells in a dose-dependent manner (Fig. 3) with the significant cytotoxic effect at $24 \mathrm{~h}$ with a concentration of $50 \mathrm{mg} / \mathrm{mL}$. MCF-7 cells in this study were exhibited anticancer activities in the concentrationdependent manner at 500 and $1000 \mu \mathrm{g} / \mathrm{ml}$. This is in agreement with other studies on the interesting anticancer activity of Tamarix species $[24,31,32]$. For instance, Tamarix aphylla leaves showed 


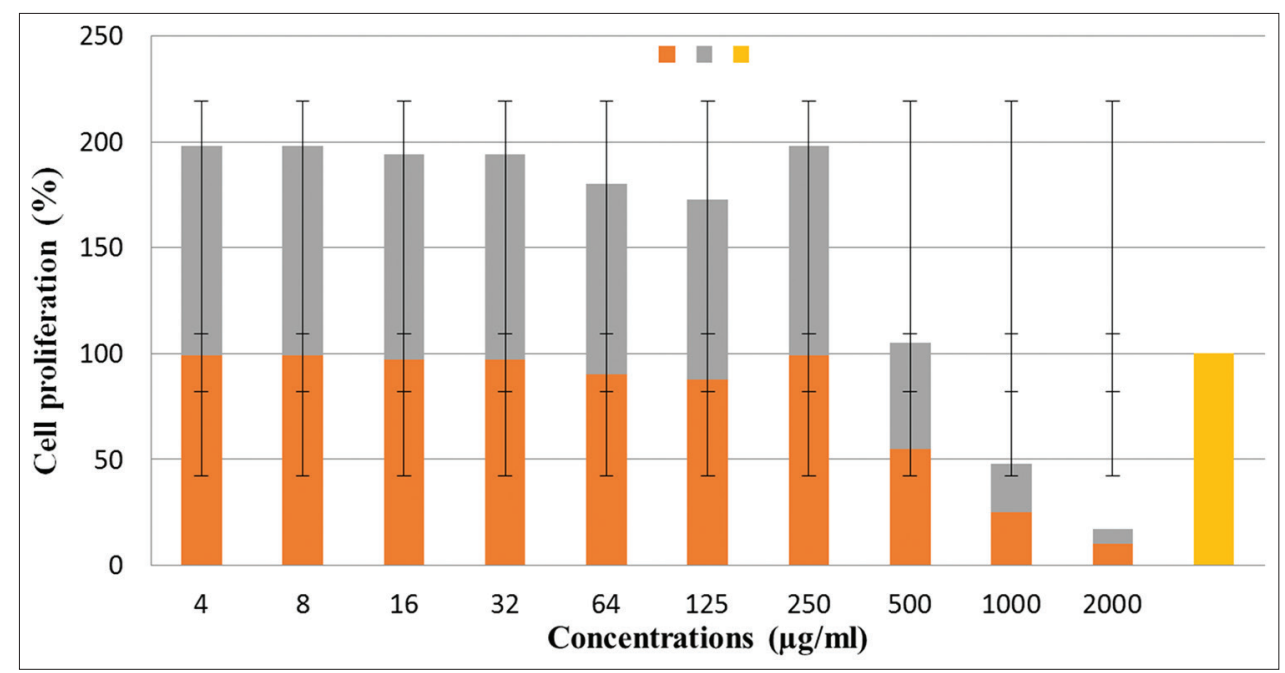

Fig. 3: Measurements of cell proliferation using Cell Titer-Blue assay in MCF-7 cancer cell line treated with different concentrations of Tamarix aphylla leaf extracts. Cells at $2 \times 10^{4} \mathrm{cells} / \mathrm{ml}$ were cultured in the absence (control/phosphate-buffered saline or Dulbecco's Modified Eagle's Medium) or in the presence of T. aphylla for $72 \mathrm{~h}$. Values represent the means of three independent experiments \pm standard deviation

anticancer capacity against human leukemia and squamous carcinoma cells. Medicinal plant possesses that anticancer activity is regarded as one of the most attractives to explore natural anticancer agent for cancer control since certain natural compounds present in medicinal plants have efficiently inhibited tumor development in various human organs [33,34]. Another study showed that methyl ferulate from Tamarix aucheriana inhibits growth and enhances chemosensitivity of human colorectal cancer cells [12]. Antiproliferative of T. aphylla leaf extracts showed better cytotoxicity activity against MCF-7 cells, and therefore, it will be used for further antiproliferative investigation.

The antibacterial activity of $T$. aphylla has been evaluated in vitro against 10 pathogenic bacteria (Table 1). Several studies have been shown that T. aphylla has antibacterial, antifungal, antiviral, and anticancer activities [13,31,35,36]. All extracts tested showed antibacterial activity with variable inhibition effects and differences in their activities against pathogenic bacteria ranging from very strong inhibition to low. However, the extracts differ in their activities against the microorganisms tested, and an increase in the extract concentration from 50 to $100 \mathrm{mg}$ resulted in a significant increase in the diameter zone of inhibition formed against all tested bacterium (Figs. 1 and 2). Our finding differs from previous studies that noted alcohols to be reliable and consistent solvents for the extraction of antimicrobial substances from medicinal plants [39]. This may be described by the fact that the secondary metabolites responsible for demonstrating antibacterial activity are greatly dependent on solvent system and collection process of metabolites from the plant sources [39]. Moreover the geographical area and environment also affect the chemical composition of the plants and lead to the variation in activity $[37,38]$. The mean zone of inhibition produced by the methanol and ethanol extracts from T. aphylla leaves against L. monocytogenes was low (Fig. 2 ), and it is generally expected that a greater number of compounds would be active against Gram- negative rather than Gram-positive bacteria [41]. In a research conducted by Joshi et al. [41] using aqueous and methanolic extract of leaves of A. hierochuntica indicated that this plant showed better antibacterial activity effects against both Gram-positive and negative bacteria, except for L. monocytogenes. These results are quite similar to that of our present study although the sample preparation and some organisms were different.

\section{CONCLUSIONS}

This study demonstrated that the T. aphylla leaf extracts showed lower toxicity on normal cell line (low toxic plant) and significantly inhibited the growth of cancer cells. The in vitro antibacterial bioassay results of this study showed that T. aphylla plant possesses potential antibacterial biomolecules against multidrug-resistant human pathogens and appeared to be a possible candidate for further pharmacological, phytochemical, and chromatographic studies to isolate and identify the bioactive compounds.

\section{ACKNOWLEDGMENTS}

The author would like to thank Dr. Maaweya Elaeed H. Awadalla, Botany and Microbiology Department, King Saud University, and the Herbarium center, King Saud University, Riyadh, Saudi Arabia, for his support in plant identification.

\section{AUTHORS' CONTRIBUTION}

The present study was designed and all in vitro experiments were performed by the author himself.

\section{CONFLICTS OF INTEREST}

The author declares that he has no conflict of interest. The present research work was conducted by following the official protocols, and there are no financial involvements of any type, with any person or organization in this regard.

\section{REFERENCES}

1. Sharif M, Banik GR. Status and utilization of medicinal plants in Rangamati of Bangladesh. Res J Agric Biol Sci 2006;2:268-73.

2. Belayachi L, Aceves-Luquero C, Merghoub N, De Mattos SF, Amzazi S, Villalonga $\mathrm{P}$, et al. Induction of cell cycle arrest and apoptosis by Ormenis Eriolepis a Morrocan endemic plant in various human cancer cell lines. Afr J Tradit Complement Altern Med 2017;14:356-73.

3. Bapat UC, Mhapsekar DR. Phytochemical investigations and antimicrobial and anticancer activities of Homonoia riparia lour. Int J Pharm Pharm Sci 2014;6:237-43.

4. Banala M, Kagithoju S, Pamulaparthi A, Edara C, Nanna R. In vitro antibacterial activity of leaf, seed, root, pod and flower extracts of Cajanus cajan (L.) millsp. Int J Pharm Pharm Sci 2015;7:265-8.

5. Doughari JH, Manzara AM. Studies on the antibacterial activity of root extracts of Carica papaya L. Afr J Microbiol Res 2007;14:37-41.

6. Doughari JH, Obidah JS. Antibacterial potentials of stem bark extracts of leptadenia lancifolia against some pathogenic bacteria. Pharmacol Oniline 2008;180:172-80.

7. Hannan A, Asghar S, Naeem T, Ullah MI, Ahmed I, Aneela S, et al. Antibacterial effect of mango (Mangifera indica Linn.) leaf extract against antibiotic sensitive and multi-drug resistant Salmonella typhi. Pak J Pharm Sci 2013;26:715-9. 
8. Doughari JH, Manzara S. In vitro antibacterial activity of crude leaf extracts of Mangifera indica Linn. Afr J Microbiol Res 2008;2:67-72.

9. Ferlay J, Soerjomataram I, Dikshit R, Eser S, Mathers C, Rebelo M, et al. Cancer incidence and mortality worldwide: Sources, methods and major patterns in GLOBOCAN 2012. Int J Cancer 2015;136:359-86.

10. Siegel R, Naishadham D, Jemal A. Cancer statistics for hispanics/ latinos, 2012. CA Cancer J Clin 2012;62:283-98.

11. Amin AR, Kucuk O, Khuri FR, Shin DM. Perspectives for cancer prevention with natural compounds. J Clin Oncol 2009;27:2712-25.

12. Abaza MS, Afzal M, Al-Attiyah RJ, Guleri R. Methylferulate from Tamarix aucheriana inhibits growth and enhances chemosensitivity of human colorectal cancer cells: Possible mechanism of action. BMC Complement Altern Med 2016;16:384.

13. Rasul A, Millimouno FM, Eltayb WA, Ali M, Li J, Li X. Pinocembrin: A novel natural compound with versatile pharmacological and biological activities. Biomed Res Int 2013;2013:379850.

14. Dall'Acqua S. Natural products as antimitotic agents. Curr Top Med Chem 2014;14:2272-85.

15. Forssten S, Ibrahim F. The elderly intestinal microbiota: Opportunities for probiotics. J Microb Biochem Technol 2011;9:1-5

16. Abouzid S, Sleem A. Hepatoprotective and antioxidant activities of Tamarix nilotica flowers. Pharm Biol 2011;49:392-5.

17. Bakr RO, Abd M, El-Raey E, Ashour RS. Phenolic content, radical scavenging activity and cytotoxicity of Tamarix nilotica (Ehrenb.) bunge growing in Egypt. J Pharmacog Phytother 2013;5:47-52.

18. Orabi MA, Taniguchi S, Sakagami H, Yoshimura M, Amakura Y, Hatano T. Hydrolyzable tannins of tamaricaceous plants. 7.1 structures and cytotoxic properties of oligomeric ellagitannins from leaves of Tamarix nilotica and cultured tissues of Tamarix tetrandra. J Nat Prod 2016;79:984-95.

19. Swaminathan C. Phytochemical analysis and antibacterial and antioxidant properties of Indigofera tinctoria L. Asian J Pharm Clin Res 2018;11:136-8.

20. Gawade B, Farooqui M. Screening of phytochemicals and in vitro antidiabetic activity of Bauhinia racemosa lam. leaves. Asian J Pharm Clin Res 2018;11:190-3.

21. Abdul L, Haitham MA, Moawia EH, Saud AR, Fahad NA. Medicinal plants from Saudi Arabia and Indonesia: In vitro cytotoxicity evaluation on Vero and HEp-2 cells. J Med Plants Res 2014;8:1065-73.

22. Marasini BP, Baral P, Aryal P, Ghimire KR, Neupane S, Dahal N, et al. Evaluation of antibacterial activity of some traditionally used medicinal plants against human pathogenic bacteria. Biomed Res Int 2015;2015:1-6.

23. Pérez C, Anesini C. In vitro antibacterial activity of Argentine folk medicinal plants against Salmonella typhi. J Ethnopharmacol 1994;44:41-6.

24. Ajaiyeoba EO, Onocha PA, Nwozo SO, Sama W. Antimicrobial and cytotoxicity evaluation of Buchholzia coriacea stem bark. Fitoterapia 2003;74:706-9.

25. Sandle T. Novel methods to address antimicrobial resistance. SOJ Microbiol Infect Dis 2014;2:1-2.
26. Sehrawat A, Sultana S. Evaluation of possible mechanisms of protective role of Tamarix gallica against DEN initiated and 2-AAF promoted hepatocarcinogenesis in male wistar rats. Life Sci 2006;79:1456-65.

27. Behera SK, Misra MK. Indigenous phytotherapy for genito-urinary diseases used by the Kandha tribe of Orissa, India. J Ethnopharmacol 2005;102:319-25.

28. Bylka W, Szaufer-Hajdrych M, Matlawska I, Goslinska O. Antimicrobial activity of isocytisoside and extracts of Aquilegia vulgaris L. Lett Appl Microbiol 2004;39:93-7.

29. Palombo EA, Semple SJ. Antibacterial activity of traditional Australian medicinal plants. J Ethnopharmacol 2001;77:151-7.

30. Chew AL, Jessica JJ, Sasidharan S. Antioxidant and antibacterial activity of different parts of Leucas aspera. Asian Pac J Trop Biomed 2012;2:176-80.

31. Samy RP, Ignacimuthu S. Antibacterial activity of some folklore medicinal plants used by tribals in Western Ghats of India. J Ethnopharmacol 2000;69:63-71.

32. Aziz MH, Kumar R, Ahmad N. Cancer chemoprevention by resveratrol: In vitro and in vivo studies and the underlying mechanisms. Int J Oncol 2003;23:17-28.

33. Boulaaba M, Tsolmon S, Ksouri R, Han J, Kawada K, Smaoui A, et al. Anticancer effect of Tamarix gallica extracts on human colon cancer cells involves Erk1/2 and p38 action on G(2)/M cell cycle arrest. Cytotechnology 2013;65:927-36.

34. Orabi MA, Taniguchi S, Yoshimura M, Yoshida T, Kishino K, Sakagami $\mathrm{H}$, et al. Hydrolyzable tannins of tamaricaceous plants. III. Hellinoyl- and macrocyclic-type ellagitannins from Tamarix nilotica. J Nat Prod 2010;73:870-9.

35. Okita K, Sakaida I, Hino K. Current strategies for chemoprevention of hepatocellular carcinoma. Oncology 2002;62:24-8.

36. Singh JP, Selvendiran K, Banu SM, Padmavathi R, Sakthisekaran D. Protective role of Apigenin on the status of lipid peroxidation and antioxidant defense against hepatocarcinogenesis in wistar albino rats. Phytomedicine 2004;11:309-14.

37. Ionescu D, Aldea IM, Bleotu C, Economescu MC, Matei L, Rizea GD, et al. Evaluation of antiviral and cytotoxic activities of Tamarix gallica and Silybum marianum extracts. Farmacia 2014;62:329-40.

38. Khan S, Ullah F, Mahmood T. In vitro antimicrobial and cytotoxic activity of Tamarix dioica Roxb. leaves. Turkish J Biol 2013;37:329-35.

39. Ahmad I, Mehmood Z, Mohammad F. Screening of some Indian medicinal plants for their antimicrobial properties. J Ethnopharmacol 1998;62:183-93.

40. Sule WF, Okonko IO, Omo-Ogun S, Nwanze JC, Ojezele MO, Ojezele OJ, et al. Phytochemical properties and in-vitro antifungal activity of Senna alata Linn. crude stem bark extract. J Med Plants Res 2011;5:176-83

41. Joshi B, Sah GP, Basnet BB, Bhatt MR, Sharma D, Subedi K, et al. Phytochemical extraction and antimicrobial properties of different medicinal plants : Ocimum sanctum (Tulsi), Eugenia caryophyllata (Clove), Achyranthes bidentata (Datiwan) and Azadirachta indica (Neem). J Microbiol Antimicrob 2011;3:1-7. 